\title{
DINAMIKA KEPEMIMPINAN PONDOK PESANTREN KIAI SYARIFUDDIN LUMAJANG
}

\author{
Syuhud \\ Institut Agama Islam Syarifuddin Lumajang \\ syuhudlu@gmail.com
}

\begin{abstract}
Abstrak
Dalam kajian manajemen, kepemimpinan merupakan salah satu aspek yang sangat menarik untuk dikaji secara serius. Konteks kepemimpinan selalu dinamis seiring dengan perkembangan kehidupan manusia, termasuk kepemimpinan di lembaga pendidikan Islam. Dasar perubahan selalu dimulai dari proses panjang perubahan nilai-nilai dasar kehidupan di masyarakat yang pada tingkat selanjutnya merubah pola komunikasi, kebutuhan dasar, dan pandangan hidup mereka. Perubahan aspek kehidupan ini berdampak pada kepemimpinan organisasi. Kajian ini difokuskan pada bagaimana masa depan lembaga pendidikan Islam dalam memberikan jawaban terhadap masyarakat dalam memenuhi kebutuhan hidupnya dilihat dari sisi kepemimpinan. Kajian ini menggunakan pendekatan kualitatif guna memberikan pengetahuan lebih mendalam tentang masalah dasar perubahan. Dengan kajian kualitatif diharapkan memberikan gambaran data di balik sesuatu yang tampak dilihat dari ide, gagasan, dan strategi dalam menata manajemen lembaga pendidikan yang sangat urgen dalam merubah arah dan pencapaian tujuan lembaga pendidikan. Kajian ini menemukan bahwa perubahan tipologi kepemimpinan merupakan tuntutan dari perubahan manajemen organisasi dalam mencapai tujuan bersama. Oleh karena itu, perubahan tipologi kepemimpinan akan memberikan dampak terhadap keberlangsungan dan kualitas pendidikan Islam di Indonesia di masa mendatang. Pemimpin lembaga pendidikan Islam saat ini dituntut untuk merancang manajemen organisasi yang dapat menggerakkan seluruh elemen kekuatan untuk menuju kemajuan organisasi dalam menjawab tantangan perubahan.
\end{abstract}

Kata Kunci: dinamika kepemimpinan, kiai, pondok pesantren, tipologi kepemimpionan 


\begin{abstract}
In the context of management studies, leadership is one of the most interesting aspects to be investigated seriously. The context of leadership is always seen as dynamic and goes hand in hand with the development of human life, including a leadership in Islamic educational institutions. The basis of the change will always start from a long process within the basic values transformation of life in society in which at a later stage changes their communication patterns, basic needs, and life outlook. The changes in this aspect of life have an impact on organizational leadership. This study focuses on how the future of Islamic educational institutions provides answers to the community in fulfilling their needs in terms of leadership. This study uses a qualitative approach to provide deeper knowledge about the basic problems of change. Using a qualitative study, it is expected that it offers such kind of data implied within the ideas, thoughts and strategies in running an educational institutions management that are very urgent in changing the direction and achieving the goals of the institution education. This study suggested that changes in leadership typology are seen as demands from organizational management changes in achieving the shared goals. Therefore, changes in leadership typology will have an impact on the sustainability and quality of Islamic education in Indonesia some years to come. The leaders of Islamic educational institutions are currently required to design organizational management that can trigger movements in all elements and strength towards organizational advancement in answering the challenges within the change itself.
\end{abstract}

Keywords: leadership dynamics, kiai, pondok pesantren, typology of leadership

\title{
Pendahuluan
}

Manusia, dengan segala kompleksitas kehidupannya memiliki banyak sisi yang bisa dikaji untuk mencapai tujuan kehidupannya. Kepemimpinan merupakan sisi yang cukup menarik untuk dikaji dalam kehidupan manusia, baik sebagai pribadi maupun sebagai makhluk sosial yang selalu berkomunikasi dengan orang lain dalam proses kehidupannya. Hidup bersama dalam komunitas masyarakat tertentu merupakan sunnatullah yang tidak bisa terhindarkan untuk membangun kebersamaan dalam memenuhi kebutuhan hidup bersama. Manusia dengan segala kelebihan dan kekurangan yang dimiliki oleh setiap orang dalam kehidupan bersama menimbulkan kebutuhan terhadap pemimpin yang dapat menggerakkan dan mengendalikan kehidupan untuk mencapai tujuan bersama di antara mereka. 
Kepemimpinan dalam lembaga pendidikan Islam merupakan salah satu tempat kehidupan bersama yang membutuhkan gerak langkah cepat dan tepat dalam mencapai sasaran yang menjadi tujuan bersama dengan hasil yang maksimal, kondisi ini membutuhkan pemimpin dengan visi dan misi yang dapat menggerakkan seluruh sistem manajemen lembaga secara cepat dan tepat. Langkah-langkah strategis yang tanpa henti untuk keberlanjutan gerak semua elemen dan unsur dalam organisasi untuk menyelesaikan pekerjaan dapat berjalan secara efektif dan efesien merupakan bagian inti dari kontinuitas hasil capaian target yang ditetapkan dengan satu komando dari seorang pemimpin.

Teori kepemimpinan yang ditulis oleh Sergiovanni mengatakan bahwa kepemimpinan kepala sekolah yang efektif memiliki peran ganda yaitu sebagai pemimpin pendidikan (educational leader) dan sebagai manajer sekolah (manager of school). ${ }^{1}$ Artinya, kepala sekolah sebagai pemimpin di samping harus memiliki kemampuan pengelolaan sekolah dengan baik juga membutuhkan ilmu pengetahuan dalam menjalankan roda kepemipinannya. Sebab, walau bagaimanapun, lembaga keagamaan Islam yang secara historis berdiri atas dasar keilmuan agama yang dimiliki dan dibutuhkan oleh masyarakat.

Dari beberapa hasil penelitian dapat digambarkan landasan proses kepemimpinan. Wieczorek dan Manard mengatakan tentang kepemimpinan kepala sekolah untuk memenuhi kebutuhan profesional yang diharapkan oleh sebuah komunitas masyarakat. ${ }^{2}$ Emin dan Ramazan berbicara tentang pelibatan masyarakat dalam proses kepemimpinan untuk mengembangkan kemampuan pemimpin dalam melaksanakan tanggung jawab kepala sekolah dan program sekolah. ${ }^{3}$ Ariel Tichnor-Wagner menyampaikan tentang kepemimpinan pendidikan dari persfektif pemenuhan kebutuhan global tanpa melihat terhadap kebutuhan

1 Imron Arifin dan Muhammad Slamet, Kepemimpinan Kiai dalam Perubahan Manajemen Pondok Pesantren, (Yogyakarta: Aditya Media, 2010), 108.

2 Wieczorek and Manard, "Instructional Leadership Challenges and Practices of Novice Principals in Rural Schools," Journal of Research in Rural Education, 2018.

3 Muhammet Emin Turkoglui and Ramazan Cansony, "Instructional Leadership Behaviors According to Perceptions of School Principals in Turkey Research Article," International Online Journal of Educational Sciences (IOJES) 2018. 
masyarakat sekitar dimana sekolah itu berada. ${ }^{4}$ Untuk mengisi ruang kosong yang belum dikaji secara mendalam, kajian ini berusaha mengungkap tentang proses kepemimpinan lembaga pendidikan Islam dari arah kebutuhan masyarakat dan budaya masyarakat dengan rasa tanggung jawab bukan hanya kepada masyarakat dunia tetapi juga kepada Allah SWT.

\section{Pembahasan}

\section{Pengertian Kepemimpinan}

Dalam konteks manajemen, kepemimpinan dipahami sebagai kemampuan seseorang mempengaruhi orang lain untuk digerakkan dalam mencapai tujuan bersama. Kepemimpinan dengan demikian merupakan alat atau sarana menggerakkan orang lain untuk melakukan sebuah pekerjaan yang diinginkan oleh pimpinan sehingga tercapai sebuah tujuan bersama. Oleh karena itu, untuk mencapai tujuan bersama di kalangan para anggota kelompok dibutuhkan sebuah manajemen organisasi yang dapat merencanakan, mengorganisasikan, menggerakkan, pembagian tugas, dan mengendalikan perjalanan organisasi untuk fokus pada tujuan bersama.

Sementara itu, Sudarwan Danim memberikan definisi kepemimpinan yang mengutip pendapat Oteng Sutisna yang mengatakan bahwa kepemimpian merupakan kemampuan mengambil inisitaif dalam situasi sosial untuk menciptakan bentuk dan prosedur baru, merancang dan mengatur perbuatan, dan semua perbuatan dapat membangkitkan kerja sama kearah tercapainya tujuan ${ }^{5}$. Menurut Peter, kepemimpinan itu merupakan proses di mana individu mempengaruhi sekelompok individu lain untuk mencapai tujuan bersama dengan beberapa komponen yaitu: kepemimpinan merupakan proses, kepemimpinan melibatkan pengaruh, kepemimpinan terjadi dalam kelompok, dan kepemimpinan melibatkan tujuan bersama. ${ }^{6}$

${ }^{4}$ Ariel Tichnor-Wagner, "Globally Minded Leadership: A New Approach for Leading Schools in Diverse Democracies," International Journal of Education Policy E Leadership, 2019.

5 Sudarwan Danim, Visi Baru Manajemen Sekolah: dari Unit Birokrasi ke Lembaga Akademik, (Jakarta: Bumi Aksara, 2006), 204. 2003), 12.

6 Peter G. Northouse, Kepemimpinan Teori dan Praktik, (Jakarta: Indeks, 
Sementara itu, Hani Handoko yang mengutip pendapat Stoner mengatakan bahwa kepemimpinan merupakan suatu proses pengarahan dan pemberian pengaruh pada kegiatan-kegiatan dari sekelompok anggota yang saling berhubungan tugasnya, dan implikasinya: pertama, kepemimpinan menyangkut orang lain bawahan atau pengikut; kedua, kepemimpinan menyangkut pembagian kekuasaan yang tidak seimbang di antara para pemimpin dan anggota kelompoknya; dan ketiga, pemimpin dapat menggunakan pengaruh terhadap bawahan/pengikutnya bagaimana bawahannya menjalankan perintahnya. ${ }^{7}$ Pembagian tugas terhadap para staf bawahan akan memberikan arti yang luas dalam menyelesaikan seluruh tugas kerja yang menjadi tanggung jawab.

Dari beberapa definisi yang dirumuskan oleh para pakar dari hasil penelitiannya, menurut Muhaimin ada hal substansial dalam konteks kepemimpinan di lembaga pendidikan yaitu adanya beberapa unsur yang harus dimiliki oleh kepala sekolah sebagai pemimpin di lembaga pendidikan. Pertama, visi. Bagi seorang pemimpin sekolah, visi merupakan titik awal untuk menjadi pemimpin besar. Kedua, keberanian. Pemimpin lembaga pendidikan harus memiliki keberani dalam bekerja untuk mencintai pekerjaannya. Ketiga, memiliki kemampuan untuk bekerja dalam alam yang realistis, artinya kepala sekolah harus bisa membedakan mana opini dan mana yang realita. Keempat, kepemimpinan kepala sekolah harus mampu menjadi pemimpin yang tidak hanya legalitas akan tetapi pemimpin yang memiliki kepedulian dan sensitivitas yang tinggi terhadap manusia. ${ }^{8}$ Visi dan misi seorang pemimpin dapat menggerakkan seluruh elemen dan unsur dalam proses kepemimpinannya dengan satu arah gerakan yaitu mencapai tujuan bersama.

\section{Tipologi Kepemimpinan}

Fungsi dan peran pemimpin sangat startegis dalam menjalankan proses manajemen organisasi termasuk organisasi lembaga pendidikan Islam. Oleh karena itu, tipe kepemimpinan yang dijalankan oleh seorang pemimpin sangat berpengaruh terhadap model manajemen yang dijalankan oleh seorang

7 T. Hani Handoko, Manajemen, (Yogyakarta: BPFE, 2013), 292.

${ }^{8}$ Muhaimin, Suti'ah, dan Sugeng Listyo Prabowo, Manajemen Pendidikan Aplikasinya dalam Penyusunan Rencana Pengembangan Sekolah/Madrasah, (Jakarta: Prenada Media Group, 2009), 31-32. 
pemimpin. Menurut para ahli, ada beberapa tipe kepemimpinan yang dijalankan oleh seseorang dalam menjalankan roda kepemimpinannya.

Pertama, tipe kepemimpinan karismatik, yaitu kepemimpinan yang menampilkan kemampuan diri sendiri dengan kelebihan yang dimiliki dengan karismatiknya yang dapat membawa para pengikut memberi atribut kepahlawanan atau kemampuan kepemimpinan yang luar biasa dengan mengamati perilaku-perilaku tertentu, dan cenderung memberikan kekuasaan para pemimpin tersebut. ${ }^{9}$ Dengan demikian, pemimpin karismatik merupakan pemimpin yang memiliki daya pikat yang tinggi sehingga kepemimpinannya diakui dan diterima oleh para pengikutnya.

Kedua, tipe kepemimpinan transformasional, yaitu kepemimpinan yang menginspirasi para pengikutnya untuk melampaui kepentingan diri mereka sendiri demi keuntungan organisasi, ${ }^{10}$ tipe seorang pemimpin yang proaktif dan meningkatkan kesadaran bawahannya tentang kepentingan kolektif inspiratif, serta membantu bawahan meraih performa yang tinggi. Mardiyah memberikan penjelasan kepemimpinan transformasional ini dengan lima indikator:

1. Attributed charima, di mana kharisma dianggap bersifat inheren dan ini hanya dimiliki oleh pemimpin kelas duania.

2. Idealized influenze, pemimpin mempengaruhi bawahannya melalui komunikasi langsung tetang pentingnya nilai, asumsi, komitmen, dan keyakinan untuk mencapai tujuan.

3. Inspirational motivation, pemimpin memberikan motivasi dan inspirasi kepada bawahan tentang tantangan dan tugas.

4. Intellectual stimulation, pemimpin mendorong bawahan untuk memikirkan dan mencari cara kerja baru dalam menyelesaikan tugas.

5. Individualized consideration, pemimpin memberikan perhatian khusus secara pribadi kepada bahwannya. ${ }^{11}$

9 Stephen P. Robbins dan Timothy A. Judge, Perilaku Oragnisasi, (Jakarta: Salemba Empat, 2015), 259.

${ }^{10}$ ibid, 261.

${ }^{11}$ Mardiyah, Kepemimpinan Kiai dalam Memelihara Budaya Organisasi, (Malang: Aditya Media Publishing, 2015), 44-45. 
Ketiga, tipe kepemimpinan otentik, yaitu kepemimpinan yang menampilkan keadaan yang sebenarnya dimiliki oleh seorang pemimpin. Sifat keaslian seseorang adalah menjadi diri sendiri menjadi kenyataan, transparan, andal, dapat dipercaya, nyata, dan benar. Seorang pemimpin otentik secara psikologis bertindak atas dirinya sendiri dari pengalaman pribadi seseorang yang menyangkut pikiran, emosi, atau kepercaryaan yang ada dalam dirinya sendiri. Proses yang menarik dari tipe kepemimpinan otentik adalah keseimbangan kedua kapasitas psikologis positif dan konteks organisasi yang sedang dia berkembang, yang menghasilkan kesadaran diri dan perilaku positif yang diatur sendiri dari para pemimpin dan rekan kerja, mendorong pengembangan diri yang positif. Pemimpin yang otentik itu percaya diri, penuh harapan, optimis, tangguh, transparan, bermoral/etis, berorientasi pada masa depan, dan mengutamakan pengembangan rekan kerja untuk menjadi pemimpin. Pemimpin otentik dianggap serupa dan terbuka untuk pengembangan dan perubahan, menurut saya definisi untuk pemimpin otentik adalah para manajer dan pemimpin sehari-hari disemua jenis dan tingkat organisasi yang mengetahui dan benar terhadap diri mereka sendiri dan kepada orang lain yang melakukan hal yang benar, memiliki kerja efektif yang berkelanjutan diwilayah tanggung jawab, unit, dan keseluruhan organisasi mereka. ${ }^{12}$

Keempat, kepemimpinan situasional, ${ }^{13}$ yaitu kepemimpinan yang berpandangan bahwa setiap individu memiliki kemampuan yang tinggi yang perlu didorong untuk memunculkan kemampuan terbaik orang lain tersebut, dan kepemimpinan yang dapat menyesuaikan dengan tingkat perkembangan orang yang sedang dipimpinnya. Oleh karena itu, kepemimpinan situasional ini mengandung empat hal yang mendasarinya yaitu: mengarahkan, melatih, mendukung dan menugaskan. Kepemimpinan situasional menjadi salah satu tipologi kepemimpinan yang dipandang dapat memotivasi untuk menjawab dan menyelesaikan masalah-masalah yang sedang dihadapi oleh para pemimpin.

${ }^{12}$ Fred Luthans, Organizational Behavior An Evidence-Based Approach, (New York: McGraw-Hill/Irwin, 2011), 433.

${ }^{13}$ Ken Blanchard, Leading at A Higher Level, (Jakarta: Gramedia, 2007), 104. 
Kepemimpinan situasional merupakan pendekatan yang dipandang cukup efektif untuk mengendalikan dan memotivasi pada bawahannya karena tipe kepemimpinan ini selalu membukan komunikasi dan menjalin kerjasama antara bawahan dan pimpinan dalam menyelesaikan tugas kerja organisasi yang dipimpinnya. Para pemimpin situasional selalu memberikan arahan dan semangat untuk mencapai kemandirian dalam tugas dan tanggung jawab, mereka selalu menginspirasi para bawahan untuk terus melakukan perubahan dan pengembangan terhadap capaian yang menjadi tujuan bersama.

\section{Dinamika dan Tipologi Kepemipinan Kiai}

Lembaga pendidikan Islam yang berada di bawah naungan Yayasan Pondok Pesantren Kiai Syarifuddin merupakan salah satu lembaga pendidikan Islam yang terus mengalami perkembangan yang signifikan menuju ke arah perbaikan kualitas mutu lulusannya. Perkembangan ini tidak lepas dari perencanaan dan pengorganisasian secara profeisonal yang setiap tahun dilakukan perbaikan oleh para pimpinan lembaga berdasarkan wewenang dan tanggung jawab mereka. Pemimpin yang profesional akan selalu melihat kekuatan, kelemahan, peluang, dan tantangan ke depan lembaga yang dipimpinnya, kompetensi pemimpin menjadi dasar arah kemajuan lembaga yang diharapkan. Kemampuan manajerial pemimpin lembaga pendidikan Islam Syarifuddin dapat digambarkan bahwa secara istiqamah mereka selalu belajar dan berbuat berdasarkan kemampuannya, kaderisasi para calon pimpinan menjadi hal urgen bagi mereka untuk terus dikembangkan, sehingga pergantian kepemimpinan dilakukan berdasarkan kesiapan para calon penggantinya, baik itu kemampuan keilmuannya, manajenerialnya, maupun kepribadiannya yang secara sosial telah diakui oleh masyarakat sekitarnya.

Kemajuan dan perkembangan lembaga pendidikan Islam di Yayasan Syarifuddin dapat dianalisasi secara periodik sejak awal berdiri tahun 1932 sampai saat sekarang. Yayasan Syarifuddin merupakan lembaga yang mengelola unit-unit lembaga pendidikan baik formal maupun nonformal (pondok pesantren), keberadaan Yayasan Syarifuddin sangat dibutuhkan oleh masyarakat sekitar dan masyarakat Kabupaten Lumajang pada umumnya, Yayasan Syarifuddin diharapkan dapat memberikan solusi terhadap persoalan-persoalan yang dihadapi dan terjadi di masyarakat. Oleh karena 
itu, para pimpinan yayasan selalu dan terus melakukan perubahan dan pengembangan lembaga sesuai dengan kebutuhan masyarakat, jawaban atas kondisi riil untuk memberikan solusi menjadi tujuan utama para pimpinan lembaga, masukan dan saran dari semua pihak menjadi pertimbangan dalam proses kepemimpinan yayasan.

Periodesasi kepemimpinan di Yayasan Syarifuddin dapat dikelompokkan menjadi empat periode.

1. Periode 1932-1954 (Kiai Syarifuddin dan Kiai Adra’i)

Periode ini merupakan awal berjalannya proses pendidikan yang dilakukan oleh Kiai Syarifuddin, secara historis beliau merupakan pendiri Pondok Pesantren Kiai Syarifuddin Lumajang, pondasi yang dibangun menuju arah masa depan yang cemerlang telah beliau letakkan secara benar dan kokoh, baik pada kondisi fisik maupun non fisik. Secara fisik konsep bangunan gedung telah beliau persiapkan secara baik, kemudian pada pondasi non fisik beliau meletakkan dasar-dasar kemandirian yaitu keikhlasan, kesabaran, dan keyakinan untuk menatap masa depan yang cerah terhadap lembaga pendidikan yang menjadi keinginan masyarakat Lumajang.

Pada periode ini pondok pesantren Kiai Syarifuddin belum memiliki lembaga pendidikan formal, proses pendidikan yang dijalankan oleh Kiai Syarifuddin hanya pengajian kitab kuning dengan metode wethonan, bandongan dan sorogan. Kiai Syarifuddin tidak pernah menempuh pendidikan formal atau tidak memiliki pengetahuan umum untuk menunjang rencana pendidikan yang beliau inginkan, beliau menjalankan hanya pada batas-batas kemampuan yang beliau miliki yaitu mengajarkan ilmu-ilmu yang ada dalam beberapa kitab kuning sebagai leteratur dalam memberikan ilmu kepada santrinya.

Hal ini disampaikan oleh Kiai Sulahak Syarif dalam sebuah wawancara dengan mengatakan bahwa "Kiai Syarifuddin merupakan kiai kampung di Desa Wonorejo yang memiliki keinginan untuk mendidik orang-orang disekitarnya agar memiliki pengetahuan agama Islam sebagai landasan dalam kehidupan mareka di masyarakat" Beliau merupakan kiai kampung yang bertahan dengan keterbatasannya namun memiliki semangat untuk memulai, beliau mendirikan mushalla sebagai tempat masyarakat mengaji, penduduk masyarakat mendatangi pengajian yang dilaksanakan oleh Kiai Syarifuddin dengan tanpa paksaan, mereka berkeinginan untuk mengetahui dan mendalami ilmu agama Islam. 
Dengan dukungan masyarakat yang begitu besar maka pada tahun 1932 Kiai Syarifuddin dimohon oleh masyarakat desa Wonorejo untuk mendirikan pondok pesantren yang diberi nama "Pondok Pesantren Mubtadi'in" yang diasuh langsung oleh Kiai Syarifuddin sendiri. Sebagai kiai kampung maka Kiai Syarifuddin tidak banyak melakukan pngembangan dengan perencanaan yang matang, beliau hanya melaksanakan dan menampung keinginan masyarakat untuk menimba ilmu pengetahuan agama Islam, namun demikian perkembangan terus terjadi atas dukungan masyarakat Wonorejo bahkan masyarakat Lumajang pada umumnya, secara kuantitas keberadaan santri terus bertambah dari masyarakat sekitar Lumajang.

Secara spesifik pondok pesantren Kiai Syarifuddin banyak mengkaji ilmu-ilmu fikih, sorrof, dan nahwu, sehingga santri pondok pesantren Kiai Syarifuddin terkenal mahir dengan ilmu alat dan ilmu fikih. Ciri khusus ini terus diperkuat dan dikembangkan secara terus menerus sehingga menjadi kekuatan dan mutu alumni santri, kondisi ini menjadi marketing bagi peningkatan santri secara kuantitas, banyak kalangan masyarakat yang memberikan apresiasi terhadap capaian pondok pesantren Syarifuddin dibidang ilmu alat dan fikih. Jumlah santri terus bertambah setiap tahun, mereka datang dari berbagai daerah di jawa timur, bahkan mereka banyak datang dari pulau Baweaan Kabupaten Gersik.

Pada masa periode ini tidak ada pengembangan pendidikan diluar pendidikan agama Islam, artinya sampai akhir hayatnya Kiai Syarifuddin tidak mendirikan lembaga pendidikan formal, beliau hanya fokus di pendidikan pesantren yang mengkaji kitab-kitab kuning salafi. Jadi santri hanya diberikan pengetahun agama Islam mulai dari awal sampai mereka kembalai ke kampung halamannya, mereka para santri betul-betul mahir dan paham tentang ilmu agama Islam khusunya ilmu sorrof, nahwu, dan ilmu fikih.

2. Periode 1954-1982 (Kiai Adra'i dan Kiai Sulahak Syarif dan Kiai Fakih Kholili)

Setelah sepeninggalannya Kiai Syarifuddin, kepemimpinan dilanjutkan oleh Kiai Adra'i sebagai penerus pengasuh Pondok Pesantren Kiai Syarifuddin, di tengah perjalannya kiai Adra'i dibantu oleh Kiai Sulahak Syarif dan Kiai Fakih Kholili. Kiai Adra'i merupakan seorang kiai yang tidak terlalu banyak mengetahui tentang perkembangan ilmu umum yang sedang diminati oleh masyarakat sehingga di awal-awal kepemimpinannya beliau tetap 
fokus melanjutkan terhadap kegiatan yang sudah ada yang dilakukan oleh Kiai Syarifuddin, secara khusus Kiai Adra'i juga memiliki kemampuan ilmu agama Islam dibidang ilmu tauhid sehingga ada beberapa kitab tambahan yang diajarkan kepada para santri yaitu kitab-kitab tauhid dan tafsir yang dikaji secara sorogan dan bandongan.

Kemajuan secara kuantitas santri pondok pesantren Kiai Syarifuddin terus bekembang dengan pesat, kebutuhan masyarakat wali santri di masyarakat terus mengalami perubahan, kemajuan masyarakat menjadi tantangan dan harapan yang harus dijawab oleh pengasuh pesantren, agar pesantren tetap eksis di mata masyarakat maka perubahan dan pengembangan harus dilakukan oleh para pengasuh pesantren sehingga pesantren mampu memberikan jawaban atas kebutuhan masyarakat dalam menyelesaikan masalah kehidupan mereka. Dengan melihat terhadap perkembangan yang terjadi di masyarakat maka pesantren Syarifuddin berupaya mencari solusi terhadap tantangan yang mereka hadapi.

Kiai Adra'i sebagai pengsuh pesantren kemudian dibantu oleh Kiai Sulahak dan Syarif dan Kiai Fakih Kholili mencoba saling bagi tugas dan pemikiran pada wilayah keilmuan masing-masing. Kiai Sulahak syarif bersama Kiai Fakih Kholili berusaha keras untuk mengembangkan proses pendidikan pada pendidikan formal, beliau melakukan konsultasi dan komunikasi dengan berbagai pihak yang dianggap bisa membantu untuk mendirikan lembaga pendidikan formal sehingga pada akhirnya 1978 diririkan Madrasah Ibtidaiyah Mubtadi'in, beberapa orang sekitar pesantren yang memiliki kemampuan ilmu umum diajak untuk membantu menjalankan lembaga pendidikan formal yang baru didirikan.

Keterbukaan komunikasi yang dibangun oleh pimpinan pesantren dengan masyarakat sekitar pesantren maupun masyarakat umum, khususnya para alumni dapat memberikan sumbangsih pemikirannya untuk pengembangan lembaga pendidikan formal yang ada di pondok pesantren Syarifuddin. Ide, pemikiran, dan usulan yang disampaikan oleh pengurus pesantren dan masyarakat kepada pimpinan pesantren dijadikan input yang dikaji oleh kiai untuk melakukan perbaikan dan pengembangan pesantren secara kontinu, pendidikan terus mengalami perubahan dan perkembangan sejalan dengan perkembangan yang terjadi di masyarakat. 
Pimpinan pesantren secara kuantitatif berhasil membangun kesadaran masyarakat sekitar tentang pentingnya pendidikan bagi anak-anak mereka, hal ini dapat dilihat semakin banyak anak-anak yang masuk di lembaga pendidikan formal yang ada di pesantren yaitu madrasah Ibtidaiyah Mubtadi'in. Semangat dan kesadaran masyarakat ini dijadikan modal utama oleh kiai sebagai pimpinan pesantren untuk terus meningkatkan pelayanan terhadap masyarakat sehingga mereka semakin merasa bahwa kehadiran pesantren dengan pendidikan formal yang dilaksanakan dianggap dapat memberikan manfaat yang sangat besar untuk kehidupan mereka dimasa depan. Masyarakat sekitar pesantren sudah mulai beranggapan bahwa anak-anak mereka di masa depan memiliki dunia yang berbeda dengan orang tuanya. Perkembangan dunia tidak bisa hanya dihadapi dengan semangat yang tinggi tetapi juga membutuhkan skill yang dapat dijadikan dasar bagi mereka untuk berbuat dan terlibat lebih jauh dalam persaingan hidup di dunia global.

Beberapa komentar masyarakat dan alumni tentang perkembangan Pesantren Syarifuddin, mereka mengatakan bahwa di zaman itu tidak mudah untuk mengembangkan pendidikan formal bagi lembaga pendidikan Islam khususnya pesantren karena pada zaman itu sangat sulit untuk mendapatkan dukungan dari pemerintah. Hal ini dirasakan oleh para santri bahwa mereka belajar di lembaga pendidikan formal Islam sangat minim sarananya, mereka mendapatkan layanan dan proses pembelajaran sangat terbatas, bahkan secara legal formal lembaga formal pendidikan masih sering dan banyak bergabung dengan lembaga lain yang sudah memiliki izin operasional. Lembaga pendidikan Islam sangat sulit untuk mendapat izin operasional, kondisi ini juga dirasakan oleh lembaga pendidikan Islam yang dilaksanakan oleh pondok pesantren Kiai Syarifuddin.

Namun demikian, pimpinan lembaga pendidikan Islam Syarifuddin yang dalam hal ini dilaksanakan oleh Kiai Sulahak Syarif dan Kiai Fakih Kholili tetap terus berusaha dan berjuang untuk mempertahankan dan mengembangkan lembaga pendidikan Islam formal untuk memberikan pendidikan kepada anak-anak masyarakat Wonorejo khususnya dan masyarakat Lumajang pada umumnya. Upaya pimpinan terus membuka komunikasi dan membangun jaringan penunjang terhadap terlaksananya pendidikan formal secara lebih baik, keterbatasan pengetahuan ilmu 
umum yang dirasakan oleh pimpinan tidak menjadi halangan untuk terus bangkit membangun lembaga pendidikan yang bisa memberikan jawaban atas masalah dan kebutuhan hidup yang dialami oleh masyarakat.

3. Periode 1982-1994 (Kiai Sulahak Syarif dan Kiai Suhadak Syarif)

Pada periode ini, lembaga pendidikan Islam Syarifuddin sudah mulai memiliki kader internal yang cukup memiliki kemampuan untuk mengelola dan mengembangkan secara lebih baik lembaga pendidikan yang mereka dirikan. Beberapa putra dan putri kelurga besar Syarifuddin sudah mulai kembali dan membantu untuk pengembangan lembaga pendidikan Islam yang ada di pondok pesantren Kiai Syarifuddin, seperti Kiai Suhadak Syarif telah menempuh pendidikan formal sampai jenjang sarjana S1. Kader-kader Yayasan Syarifuddin yang memiliki kemampuan ilmu umum terus membangun network dengan berbagai stakeholder yang dapat memberikan dukungan kepada lembaga baik materiil maupun non materiil.

Kemampuan para penerus Yayasan Syarifuddin menunjukkan baktinya yang luar biasa, mereka terus melakukan usaha yang kontinu dan responsif terhadap perubahan dan perkembangan yang terjadi di masyarakat luas sebagai pengguna jasa pendidikan yang mereka laksanakan. Para pemimpin Yayasan Syarifuddin menyadari betul terhadap perubahan yang menjadi tantangan bagi mereka di masa depan, kerjasama dengan berbagai pihak untuk meningkatkan kualitas menjadi pilihan yang rasional untuk mendapatkan posisi daya saing yang strategis dihadapan para kompetitor pengembang lembaga pendidikan Islam di sekitar Lumajang khusus dan masyarakat global pada umumnya.

Langkah strategis yang direncanakan bagi para pimpinan syarifuddin adalah melakukan pengembangan pada sisi kelembagaan yaitu dengan mendirikan lembaga pendidikan Islam pada tingkat yang lebih tinggi yaitu mendirikan madrasah Tsanawiyah pada tahun 1983. Lembaga yang baru ini diharapkan bisa memberikan harapan yang besar kepada masyarakat tentang kesiapan dan kemajuan Yayasan Syarifuddin untuk terus berjuang mambantu masyarakat dalam memenuhi kebutuhan terhadap dunia pendidikan bagi anak-anak mereka dimasa depan. Langkah ini mendapat dukungan yang sangat besar dan luas dari masyarakat, secara kuantitas dapat dilihat dari banyaknya santri 
yang mondok dan masuk di lembaga yang baru didirikan oleh Yayasan Syarifuddin, santri laki-laki dan perempuan terus mengalami peningkatan setiap awal masuk tahun baru pelajaran lembaga pendidikan formal.

Usaha perkembangan terus dilakukan oleh Yayasan Syarifuddin, mereka melihat antusiasme masyarakat yang semakin besar untuk melanjutkan pendidikan anak-anak mereka kepada jenjang pendidikan yang lebih tinggi, oleh karena itu Yayasan Syarifuddin pada tahun 1987 mendirikan lembaga pendidikan madrasah Aliyah sebagai wadah lanjutan dari mereka yang keluar dari madrasah Tsanawiyah Syarifuddin. Keberadaan madrasah Aliyah Syarifuddin semakin membuat masyarakat yakin bahwa Yayasan Syarifuddin telah memiliki kesiapan untuk menghadapi perubahan dan perkembangan zaman yang terjadi dalam kehidupan manusia. Para pimpinan Yayasan Syarifuddin terus membukan kerjasama dan berkomunikasi dengan berbagi pihak sebagai bentuk keterbukaan pengelola yayasan terhadap masyarakat luas.

4. Periode 1994-sekarang (Kiai Sulahak Syarif dan Kiai Adnan Syarif)

Perkembangan Yayasan Syarifuddin terus berjalan secara dinamis dan kontinu sesuai dengan kemampuan para pimpinannya untuk melakukan perubahan. Kesiapan para calon pemimpin Syarifuddin terus ditingkatkan sesuai dengan perkembangan dan tuntutan perubahan masyarakat. Berbagai kebutuhan kemampun pengelolan lembaga pendidikan terus dipelajari oleh para perus yayasan. Kiai Adnan Syarif merupakan kader penerus yang memiliki pengalaman keilmuan yang cukup mampuni, beliau lulusan sarjana S1 King Abdul Aziz arab Saudi bidang ilmu sastra arab dan lulusan pascasarjana S2 UNISLA jurusan Manajemen Pendidikan Islam. Kehadiran Kiai Adnan Syarif memberikan arah baru manajemen pengelolaan lembaga pendidikan oleh para pimpinan Syarifuddin yang menjadi fokus perhatian, sehingga harapan dan tujuan yang ingin dicapai dapat berhasil secara maksimal, Sumber Daya Insani (SDI) yang menjadi motor penggerak perkembangan menjadi salah satu indikator penentu terhadap perubahan yang direncanakan oleh Yayasan Syarifuddin.

Dengan kemampuan dasar pengetahuan yang dimiliki oleh para pimpinan Syarifuddin maka dapat dibuktikan bahwa komunikasi dalam membangun kerjasama dengan berbagai pihak 
mendapat sambutan yang signifikan dari berbagai pihak, baik dari pemerintah, masyarakat, dan para alumni. Jaringan dengan para pengguna jasa pendidikan maupun lembaga penopang lembaga berjalan secara harmonis, Yayasan Syarifuddin banyak mendapat dukungan baik finansial maupun dukungan moral, peluang yang didapat oleh Yayasan Syarifuddin semakin besar untuk terus maju menuju persaingan global yang sedang terjadi di masyarakat, namun demikian tantangan yang mereka hadapi juga tidak ringan karena perkembangan terus terjadi tanpa batas.

Kemampuan manajerial para pengelola lembaga pendidikan Islam Syarifuddin terus menunjukkan eksistensinya. Pada tahun 2004 dengan kualitas Sumber Daya Insani (SDI) yang mampuni mereka mendirikan perguruan tinggi Syarifuddin dengan nama Sekolah Tinggi Ilmu Tarbiyah (STIT) Syarifuddin. STIT Syarifuddin merupakan lembaga pendidikan tertinggi yang bergengsi bagi sebuah yayasan penyelenggara pendidikan. Yayasan Syarifuddin merupakan salah satu yayasan pondok pesantren yang memiliki lembaga perguruan tinggi di Kabupaten Lumajang pada saat itu dengan pengelolaan yang profesional.

STIT Syarifuddin mendapat kepercayaan sangat baik dari masyarakat, hal ini dapat dilihat dari kuantitas jumlah mahasiswa yang terus meningkat setiap tahunnya. Mereka bekerja sama dengan lembaga-lambaga pendidikan di Lumajang baik yang negeri maupun swasta. Kerjasama dilakukan tidak hanya secara kuantitas tetapi juga dalam rangka untuk membangun kualitas para lulusan perguruan tinggi Syarifuddin. Lembaga-lembaga pendidikan negeri seperti SMA Negeri se-Kabupaten Lumajang merupakan lembaga mitra tempat-tempat para mahasiswa fakultas Tarbiyah untuk melaksanakan Praktik Pengalaman Lapangan (PPL), mereka pengelola lembaga pendidikan negeri percaya dan memberikan akses yang seluas-luasnya kepada STIT Syarifuddin untuk meningkatkan mutu lulusannya.

Dengan kepercayaan masyarakat yang begitu besar kepada perguruan tinggi maka secara kelembagaan terus dilakukan pengem-bangan dan peningkatan status kelembagaan, pada tahun 2014 STIT Syarifuddin menjadi Institut Agama Islam Syarifuddin (IAI Syarifuddin) dengan tiga fakultas yaitu: Fakultas Tarbiyah, Fakultas Ekonomi dan Bisnis Islam (FEBI), dan Fakultas Dakwah. Kualitas mutu lulusan menjadi fokus peningkatan kemampuan nilai saing IAI Syarifuddin dalam menghadapi perubahan global dalam 
segela bidang kehidupan masyarakat, berbagai upaya dilakukan oleh para pengelolan perguruan tinggi, termasuk membangun jaringan kerjasama dengan berbagai pihak terus diusahakan termasuk kerjasama dengan perguruan tinggi luar negeri dalam rangka pertukaran mahasiswa untuk melakukan praktik dan penelitian.

Kemudian pada tahun 2012 Yayasan Syarifuddin mendirikan SMK Syarifuddin sebagai bentuk lanjutan pengembangan lembaga pendidikan yang ada untuk menampung keinginan masyarakat dalam memenuhi kebutuhan anak-anak masa depan pada bidang kemampuan elektronik. Lembaga pendidikan SMK Syarifuddin ini juga disambut baik oleh masyarakat Lumajang, jumlah peserta didik banyak berdatangan dari berbagai daerah pelosok Kabupaten Lumajang untuk melanjutkan sekolah di SMK Syarifuddin. Berdirinya SMK Syarifuddin menambah bukti bahwa kepeimpinan Yayasan Syarifuddin berkembang secara dinamis dalam konteks perubahan zaman yang begitu cepat dalam segala aspek kehidupan, para pimpinan memiliki kualitas kemampuan yang dapat diandalkan untuk bersaing secara profesional dalam mengelola lembaga pendidikan Islam dengan kualitas lulusan yang dapat bersaing dalam bursa pasar kerja.

Gambaran perubahan dan dinamika yayasan Syarifuddin berdasarkan kemampuan dan tipologi kepemimpinan di setiap masanya, dapat digambarkan dengan gambar dan tabel sebagai berikut:

Tabel 1. Profil dan Tipe Kepemimpinan Pondok Pesantren

\begin{tabular}{|c|c|c|c|c|}
\hline No. & Nama & $\begin{array}{c}\text { Pengalaman } \\
\text { Pendidikan }\end{array}$ & $\begin{array}{c}\text { Tipe } \\
\text { Kepemimpinan }\end{array}$ & $\begin{array}{c}\text { Periode } \\
\text { Kepemimpinan }\end{array}$ \\
\hline 1 & Kiai Syarifuddin & Pondok Pesantren & Kharismatik & $1932-1954$ \\
\hline 2 & Kiai Adra’i & Pondok Pesantren & Kharismatik & $1954-1982$ \\
\hline 3 & $\begin{array}{l}\text { Kiai Fakih } \\
\text { Kholili }\end{array}$ & Pondok Pesantren & Kharismatik & $1982-1993$ \\
\hline 4 & $\begin{array}{l}\text { Kiai Sulahak } \\
\text { Syarif }\end{array}$ & Pondok Pesantren & $\begin{array}{l}\text { Kharismatik - } \\
\text { otentik }\end{array}$ & 1993-sekarang \\
\hline 5 & $\begin{array}{l}\text { Kiai Syuhadak } \\
\text { Syarif }\end{array}$ & $\begin{array}{l}\text { - Pondon } \\
\text { pesantren } \\
\text { - S1 Tebuireng } \\
\text { Jombang }\end{array}$ & $\begin{array}{l}\text { Kharismatik- } \\
\text { demokratis- } \\
\text { otentik }\end{array}$ & $1982-1994$ \\
\hline
\end{tabular}




\begin{tabular}{|c|l|l|l|l|}
\hline 6 & Kiai Adnan & $\begin{array}{l}\text { - Pondok } \\
\text { Pesantren } \\
\text { Syarif }\end{array}$ & $\begin{array}{l}\text { Kharismatik- } \\
\text { otentik- } \\
\text { Aziz Suadi } \\
\text { - S2 Unisla }\end{array}$ & situasional \\
\hline
\end{tabular}

Dari deskripsi data di atas, terdapat beberapa poin yang menjadi konsentrasi kajian ini. Pertama, kemampuan individu pemimpin dalam melakukan proses kepemimpinan terhadap sebuah organisasi atau lembaga pendidikan sangat menentukan. Kemampuan personal dalam hal manajerial maupun keilmuan dasar bidang konsentrasi pengembangan lembaga pendidikan merupakan salah aspek yang sangat penting untuk dimiliki. Visimisi besar seorang pemimpin harus diterjemahkan ke dalam lembaga pendidikan, dapat diwujudkan dan dijabarkan ke dalam strategi perencanaan dan capaian yang diharapkan bersama. Kedua, kemampuan keilmuan yang dimiliki seorang pemimpin memiliki korelasi yang signifikan dengan perubahan dan perkembangan lembaga pendidikan yang dipimpinnya. Ketiga, perkembangan yang terjadi di yayasan Syarifuddin berjalan secara konsisten dan kontinu pada setiap generasi dengan tipologi kepemimpian sesuai dengan dasar keilmuan yang mereka miliki.

Tabel 2. Profil dan Tipe Kepemimpinan Pondok Pesantren

\begin{tabular}{|c|c|c|c|}
\hline No. & Kepemimpinan & Tahun & Perkembangan \\
\hline 1 & $\begin{array}{l}\text { Kiai Syarifuddin } \\
\text { dan Kiai Adra'i }\end{array}$ & $1932-1954$ & $\begin{array}{l}\text { Pondok pesantren dengan } \\
\text { pengajian kitab kuning }\end{array}$ \\
\hline 2 & $\begin{array}{l}\text { Kiai Adra'i dan } \\
\text { Kiai Sulahak } \\
\text { Syarif dan Kiai } \\
\text { Fakih Kholili }\end{array}$ & $1954-1982$ & $\begin{array}{l}\text { Pondok pesantren (kitab) dan } \\
\text { Madrasah Ibtidaiyah }\end{array}$ \\
\hline 3 & $\begin{array}{l}\text { Kiai Sulahak } \\
\text { Syarif dan Kiai } \\
\text { Syuhada Syarif }\end{array}$ & $1982-1994$ & $\begin{array}{l}\text { Pondok pesantren (kitab), } \\
\text { Madrasah Ibtidaiyah, madrasah } \\
\text { Tsanawiyah, dan Madrasah } \\
\text { Aliyah }\end{array}$ \\
\hline 4 & $\begin{array}{l}\text { Kiai Sulahak } \\
\text { Syarif dan Kiai } \\
\text { Adnan Syarif }\end{array}$ & $\begin{array}{l}\text { 1994- } \\
\text { sekarang }\end{array}$ & $\begin{array}{l}\text { Pondok pesantren (kitab) PAUD, } \\
\text { TK, Madrasah Ibtidaiyah, } \\
\text { Madrasah Tsanawiyah, Madrasah } \\
\text { Aliyah, SMK, dan perguruan } \\
\text { tinggi (IAI Syarifuddin) }\end{array}$ \\
\hline
\end{tabular}


Perubahan dan perkembangan yang terjadi di yayasan Syarifuddin sebagai penyelenggara pendidikan berjalan secara lineir antara perubahan dan pergantian pimpinan, artinya pergantian pimpinan dengan kemampuan masing-masing pimpinan mengakibatkan terjadinya perubahan secara kelembagaan, kemampuan keilmuan pimimpin memiliki dampak yang signifikan terhadap kemajuan dan perkembangan lembaga, sebagaimana Gambar 1.

Dalam beberapa banyak literatur dikatakan tentang beberapa tipe perubahan yang terjadi dalam sebuah organisasi, seperti pendapat E. Mark Hanson yang tulis oleh Nur Efendi yaitu peru-bahan terencana, perubahan spontan, dan perubahan evalusioner. ${ }^{14}$ Namun demikian hasil kajian ini berdasarkan data empirik hanya berada pada wilayah perubahan yang terencana sesuai dengan visi-misi besar pendiri lembaga Syarifuddin sebagai panduan bagi para penerus pimpinan selanjutnya. Para pemimpin yayasan Syarifuddin merupakan pemimpin visioner yaitu pemimpin yang memiliki dan selalu berorientasi ke masa depan, apa yang ingin diwujudkan di masa depan dari realitas yang sedang dihadapi ${ }^{15}$, mereka menempatkan tujuan dan perubahan sebagai sesuatu yang harus berjalan secara bersamaan sesuai dengan perkembangan yang terjadi di masyarakat.

Proses perubahan terjadi secara konsisten

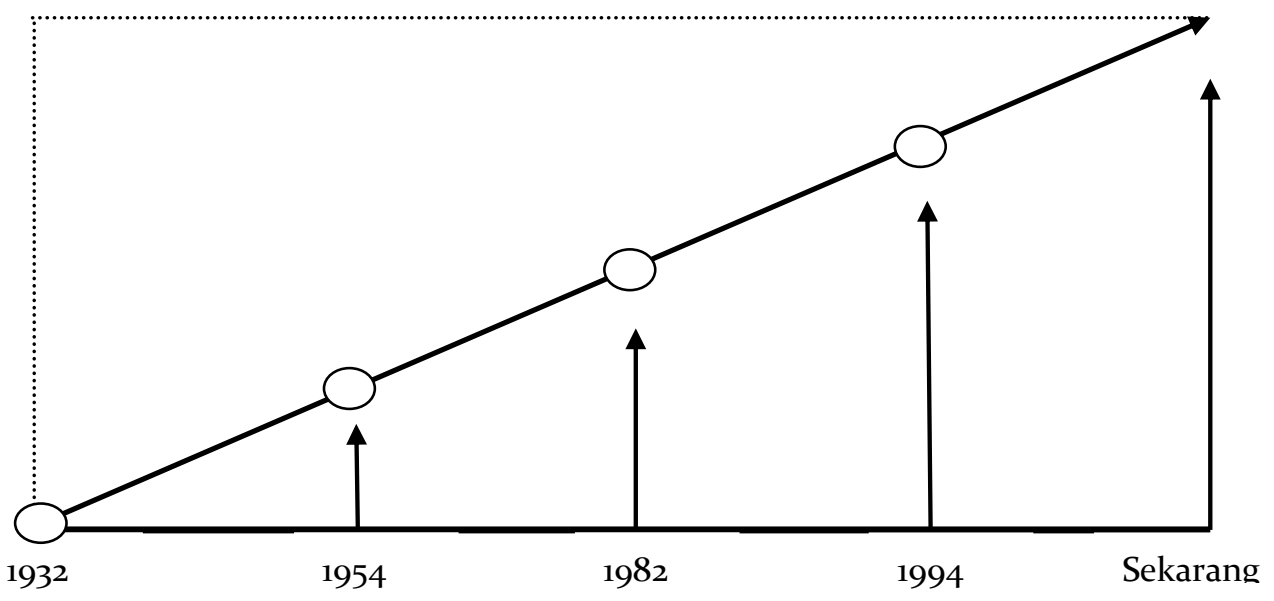

Gambar 1. Kepemimpinan dan Dinamika Pondok Pesantren

${ }^{14}$ Nur Efendi, Manajemen Perubahan di Pondok Pesantren, (Yogyakarta: Teras, 2014), 58.

15 Marno dan Triyo Supriyatno, Manajemen dan Kepemimpinan Pendidikan Islam, (Bandung: Refika Aditama, 2008), 57. 
Dengan latar belakang pendidikan pesantren para pemimpin Yayasan Syarifuddin memiliki karakter yang kuat dengan nilai-nilai spiritual Islam, mereka memiliki kepercayaan yang tinggi tentang harapan dan doa kepada Allah SWT. Raja Bambang menyampaikan tentang spiritual dari aspek pendekatan "nurani" termanifestasi dalam lima komponen yaitu rasa iman yang kuat, mengerjakan dengan niat dan ikhlas, sikap rendah hati, kepercayaan diri yang tinggi, dan berkelimpahan dalam menerima ketentuan Allah SWT. ${ }^{16}$ Melihat teori Raja Bambang ini maka mereka para pemimpin Syarifuddin melakukan proses kepemimpinan dengan pendekatan hati "nurani" yang menjadi landasan mereka melangkah jauh kedepan dengan cita-cita besar untuk kebaikan hidup generasi masa depan.

Data di lapangan juga menunjukkan bahwa pengalaman pendidikan seseorang memberikan dampak yang signifikan terhadap pola pikir, pemahaman, dan tindakan dalam menjalani perkerjaan. Pengalaman dapat membangun kerjasama yang efektif antara atasan dan bawahan, antara pimpinan dan pengikutnya. Kondisi ini dapat dilihat dalam pola kepemimpinan di Yayasan Syarifuddin sehingga terbangun efektivitas kepemimpinan manajemen lembaga pendidikan. Ada beberapa faktor yang yang mempengaruhi efektivitas kepemimpinan yang di tulis Nanang Fatah yang mengutip pendapat Jodeph Reitz yaitu: Pertama, kepribadian (personality) pengalaman masa lalu dan harapan pemimpin; Kedua, harapan dan perilaku atasan; Ketiga, karakteristik harapan dan perilaku bawahan; Keempat, kebutuhan tugas bawahan dan setiap tugas mempengaruhi pemimpin; Kelima, iklim dan kebijakan organisasi mempengaruhi perilaku bawahan; Keenam, harapan dan perilaku rekan. ${ }^{17}$ Beberapa faktor pendukung terhadap efektivitas manajemen lembaga pendidikan menjadi ciri khas tersendiri di Yayasan Syarifuddin, mereka mengimplementasikan dalam sistem dan pola kepemimpinannya.

Kemudian dapat ditarik pemahaman bahwa kepemimpinan pendidikan di Yayasan Syarifuddin banyak menggunakan pendekatan spiritual sebagai ciri khas lembaga pendidikan Islam, seperti membangun kepercayaan terhadap semua elemen dan faktor

16 Raja Bambang Sutikno, The Power of $4 Q$ for $H R$ \& Company Development, (Jakarta: Gramedia Pustaka Utama, 2010), 63-111.

${ }_{17}$ Nanang Fatah, Landasan Manajemen Pendidikan, (Bandung: Remaja Rosdakarya, 2011), 98-99. 
pendukung terhadap terlaksananya proses kepemimpinan lembaga pendidikan Islam, Toto Tasmara memberikan gambaran terhadap sosok seorang pemimpin yaitu: Pertama, credibility untuk mendapat kepercayaan dari pengikutnya. Kedua, competent atau kapabilitas yaitu kemampuan seorang pemimpin. Ketiga, confident rasa percaya diri seorang pemimpin. Keempat, courage kepercayaan para pengikut terhadap pimpinan. Kelima, commitment keyakinan yang mengikat semua unsur. Keenam, creative keyakinan pemimpin bahwa kehadirannya dapat memberikan penerangan kepada pengikutnya. Ketujuh, change keyakinan untuk melakukan perubahan. Kedelapan, challenge pemimpin sejati senang dengan tantangan. Kesembilan, consistence kemampuan untuk bersikap secara taat asas. Kesembilan, communication skill kemampuan seorang pimpinan untuk menyampaikan gagasannya. ${ }^{18}$ Teori ini dapat ditemukan dalam praktik-praktik kepemimpinan di Yayasan Syarifuddin sehingga perubahan dan perkembangan terus terjadi sesuai dengan perkembangan yang terjadi di masyarakat.

\section{Simpulan}

Gambaran kepemimpinan di lembaga pendidikan Islam yang di praktekkan di yayasan Syarifuddin dapat disimpulkan: Pertama, pengalaman pendidikan seorang pemimpin memberikan dasar terhadap tipologi kepemimpinan yang dilakukan oleh seorang pemimpin dalam melakukan proses kepemimpinan di lembaga pendidikan Islam. Kedua, kemampuan seorang pemimpin berdasarkan pengalaman pendidikan memiliki korelasi dengan perubahan dan perkembangan lembaga pendidikan Islam, baik secara kelembagaan maupun akademik, baik secara kuantitas maupun kualitas. Ketiga, tipologi kepemimpinan seorang pemimpin dapat dilahat dari pengalaman pendidikan seseorang pemimpin, baik dalam komunikasi maupun dalam manajemen pengelolaan lembaga pendidikan yang di pimpinnya.

\section{Referensi}

Arifin, Imron \& Muhammad Slamet. Kepemimpinan Kiai dalam Perubahan Manajemen Pondok Pesantren. Yogtakarta: Aditya Media, 2010.

18 Toto Tasmara, Spiritual Centered Leadership, (Jakarta: Gema Insani, 2006), 46-78. 
Blanchard, Ken. Leading At A Higher Level. Jakarta: Gramedia, 2007.

Danim, Sudarwan. Visi Baru Manajemen Sekolah dari Unit Birokrasi ke Lembaga Akademik. Jakarta: Bumi Aksara, 2006.

Efendi, Nur. Manajemen Perubahan di Pondok Pesantren. Yogyakarta: Teras, 2014.

Fatah, Nanang. Landasan Manajemen Pendidikan. Bandung: Remaja Rosdakarya, 2011.

Handoko, T. Hani. Manajemen. Yogyakarta: BPFE, 2013.

Luthans, Fred. Organizational Behavior An Evidence-Based Approach. New York: McGraw-Hill/Irwin, 2011.

Mardiyah. Kepemimpinan Kiai dalam Memelihara Budaya Organisasi. Malang: Aditya Media Publishing, 2015.

Muhaimin, Sutiah, \& Sugeng Listyo Prabowo. Manajemen Pendidikan Aplikasinya dalam Penyusunan Rencana Pengembangan sekolah/Madrasah. Jakarta: Prenada Media Group, 2009.

Northouse, Peter G. Kepemimpinan Teori dan Praktik, Jakarta: Indeks, 2003.

Robbins, Stephen P. \& Timothy A. Judge. Perilaku Oragnisasi. Jakarta: Salemba Empat, 2015.

Supriyanto, Triyo \& Marno. Manajemen dan Kepemimpinan Pendidikan Islam. Bandung: Refika Aditama, 2008.

Sutikno, Raja Bambang. The Power of $4 Q$ for $H R$ \& Company Development. Jakarta: Gramedia Pustaka Utama, 2010.

Tasmara, Toto. Spiritual Centered Leadership. Jakarta: Gema Insani Press, 2006.

Tichnor-Wagner, Ariel. "Globally Minded Leadership: A New Approach for Leading Schools in Diverse Democracies." International Journal of Education Policy \& Leadership, 2019.

Turkoglui, Muhammet Emin \& Ramazan Cansony. "Instructional Leadership Behaviors According to Perceptions of School Principals in Turkey Research Article." International Online Journal of Educational Sciences (IOJES) 2018. 
JIEMAN: Journal of Islamic Educational Management

Wieczorek and Manard, "Instructional Leadership Challenges and Practices of Novice Principals in Rural Schools," Journal of Research in Rural Education, 2018. 